\title{
ANALYSiS OF Wind Velocity DATa in THE AREA OF BJELASNICA IN PERIOD FroM 2000-2010
}

\author{
Halima Hadziahmetovic, Ismira Ahmovic \& Rejhana Blazevic
}
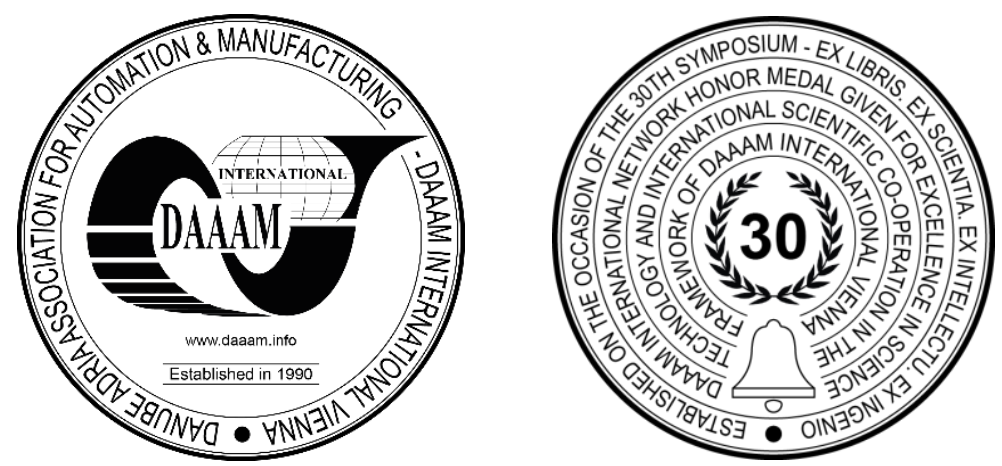

This Publication has to be referred as: Hadziahmetovic, H[alima]; Ahmovic, I[smira] \& Blazevic, R[ejhana] (2019). Analysis of Wind Velocity Data in the Area of Bjelasnica in Period from 2000-2010, Proceedings of the 30th DAAAM International Symposium, pp.0223-0231, B. Katalinic (Ed.), Published by DAAAM International, ISBN 978-3-90273422-8, ISSN 1726-9679, Vienna, Austria

DOI: $10.2507 / 30$ th.daaam.proceedings.029

\begin{abstract}
Constant growth of energy sources, then the increase in the price of electricity and the intensification of the effects of greenhouse gases is the main reason for the analysis of wind potential in the area of the Canton Sarajevo. In this paper analysis wind velocity data for the period from 2000 to 2010 for Bjelasnica, obtained from the Federal Hydrometeorological Institute of Bosnia and Herzegovina. After analysis wind velocity, a more precise assessment of wind potential in the Bjelasnica area was given and guidelines for further research.
\end{abstract}

Keywords: renewable energy sources; wind velocity; wind potential; meteorological station; wind rose.

\section{Introduction}

In Bosnia and Herzegovina, the number of potential locations for the construction of wind farms has been estimated at about 30 locations in the southern part of Bosnia and Herzegovina along the border with Croatia, which, by all observed characteristics, represents the highest wind potential in Bosnia and Herzegovina. The total wind potential of the observed sites with viewing the available space is about $900 \mathrm{MW}$. If the availability of suitable premises (grid connection, environmental protection, etc.) is not taken into account, the total technical wind potential is much higher and is estimated at around $2000 \mathrm{MW}$ [1], [7]. At the moment, a wind farm Mesihovina near Tomislavgrad has been built in Bosnia and Herzegovina, with a total of 22 wind turbines of the SWT-23-108 type, with a total installed capacity of 50,6 MW.

The wind power plant Mesihovina is currently the only wind farm in Bosnia and Herzegovina used for energy purposes, but given the development of technology and the overall trend in wind utilization in the world, it is realistic to expect that in Bosnia and Herzegovina there will be an increase in the construction of wind farms and their integration into energy the system. The extent to which the wind power program will be intensive in Bosnia and Herzegovina will depend most on the attitude and moves of state and entity governments in terms of harnessing wind energy. The first step in defining the policy goals, the use of wind energy, is to look at energy resources, analyzing the available data on wind potential in Bosnia and Herzegovina. 


\section{Measurement data in Bosnia and Herzegovina}

The first measurements of wind velocity, direction and other characteristics began in April 2002 at the site of Sveta Gora- Podveležje, and the exploration and analysis of the area began much earlier. In the period from 2004 to the present, measurements were made in the territory of Herzegovina at about a dozen potential locations, including measurements from the basic meteorological network of Bosnia and Herzegovina, which are most often established for other purposes (e.g., monitoring and weather forecasting in populated areas), so they can only partially be used for energy assessment of wind potentials in remote hilly and mountainous locations, especially in so-called locations, complex terrain. The results of the said measurement are available only for the two-year period 2004-2005. Since wind is a spatially and temporally variable source, annual variations in average wind velocity can be relatively variable (30\% or more), so wind data must be measured over many years to obtain a relevant long-term estimate of wind energy potential at some area.

Wind velocity at selected locations of Herzegovina in 2004-2005. years vary from 7 to $9 \mathrm{~m} / \mathrm{s}$. Applying extrapolation models and placing the measurement period in the context of a multi-year period at these locations at a height of $50 \mathrm{~m}$ above the ground, it is estimated that in most cases, average annual wind velocity ranging from 6 to $8 \mathrm{~m} / \mathrm{s}$ [1], [2]. Therefore, the area of southern Bosnia and Herzegovina can be considered the most promising for wind farm locations, which are located in the area marked by the red lines in Figure 1.

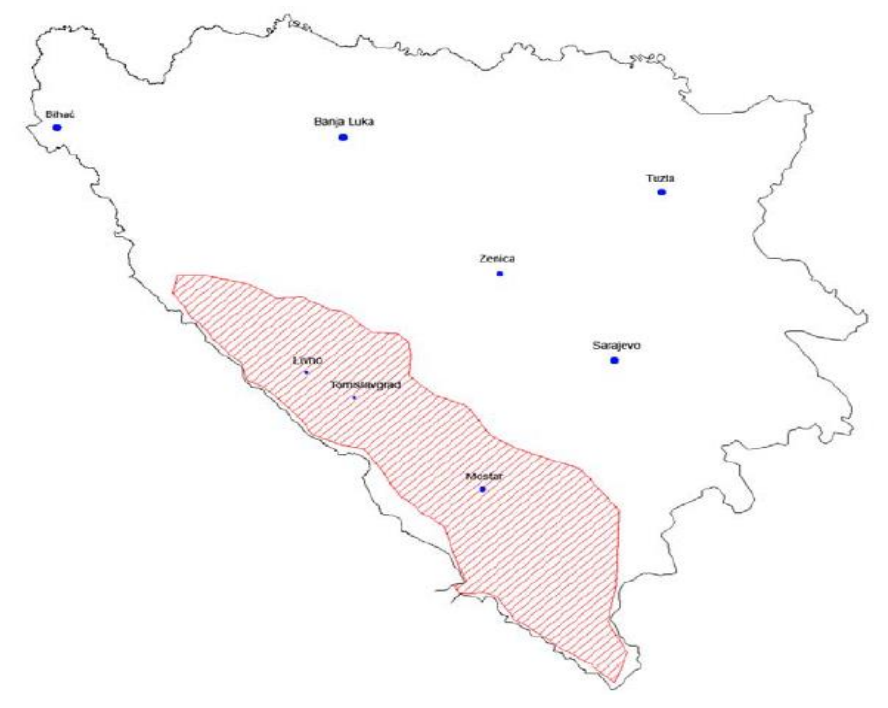

Fig.1. The area of southern Bosnia and Herzegovina can be considered the most promising for wind farm locations [1]

A major problem in the area of the city of Sarajevo (Canton of Sarajevo) is that during the winter period there is an increase in the concentration of harmful gases in the atmosphere (primarily $\mathrm{CO}_{2}$ ), as a result of the intensive use of fossil fuels. Constant growth of energy sources, then the increase in the price of electricity and the intensification of the effects of greenhouse gases is the main reason for the analysis of wind potential in the area of the Canton of Sarajevo. The paper analyzes and processes wind velocity data for the period from 2000 to 2010 for the area of Bjelasnica, obtained from the Federal Hydrometeorological Institute of Bosnia and Herzegovina. The input data used for this analysis are: average monthly wind velocity, maximum monthly wind velocity and annual average wind velocity. After analyzing data for the wind, a more accurate assessment of the wind potential in the area of Bjelasnica was given and gave guidelines for further research [4].

Paper [4] analyzes data obtained from the Federal Hydrometeorological Institute of Bosnia and Herzegovina related to the wind velocity in the area of the city of Sarajevo. Data obtained from the Federal Hydrometeorological Institute are the annual average wind velocity, average monthly wind velocity and maximum monthly wind velocity for the period from 2001 to 2010 . From this analysis of the maximum wind velocity for the period from 2001 to 2010 , it can be concluded that in the area of the city of Sarajevo there is a wind power potential, since the maximum wind velocity ranges from 8,3 to $25,9 \mathrm{~m} / \mathrm{s}$, and the maximum amount of electricity is achieves at a wind velocity of about $12 \mathrm{~m} / \mathrm{s}$. From this data analysis of the average wind velocity, it can be determined that the wind turbine does not have continuous operation, since the values range from 0 to $2,6 \mathrm{~m} / \mathrm{s}$, and for the continuous operation of the wind turbine the average wind velocity should be above $3 \mathrm{~m} / \mathrm{s}$. Because of the average wind velocity the city of Sarajevo, we decided to further explore the location Bjelasnica in the Canton Sarajevo. 


\section{Measurements of wind velocities in the meteorological station Bjelasnica}

Bjelasnica is a mountain in the central part of Bosnia and Herzegovina, located southwest of the city of Sarajevo. Just as the neighboring Jahorina and Bjelasnica belong to the Dinaric mountain system. At the highest point (2067 $\mathrm{m}$ above sea level) a significant meteorological station was built, which is also the highest inhabited point in Bosnia and Herzegovina, whose width geography is $43^{\circ} 43^{\prime}$ and lenght geography is $18^{\circ} 16^{\prime}$. The meteorological station Bjelasnica started operating in 1895. The metrological station Bjelasnica (Figure 2) observes and measures temperature, extreme temperatures, precipitation, wind, cloudiness, air pressure and relative humidity and insolation. The average annual temperature is only $0,7^{\circ} \mathrm{C}$, due to extremely low winter temperatures. The highest temperature reaches $24^{\circ} \mathrm{C}$ and the lowest is $-41^{\circ} \mathrm{C}$. In summer it is covered with dense green grass, and in winter and up to $3 \mathrm{~m}$ high snow. Strong winds and thunderstorms are the climatic feature of this mountain.
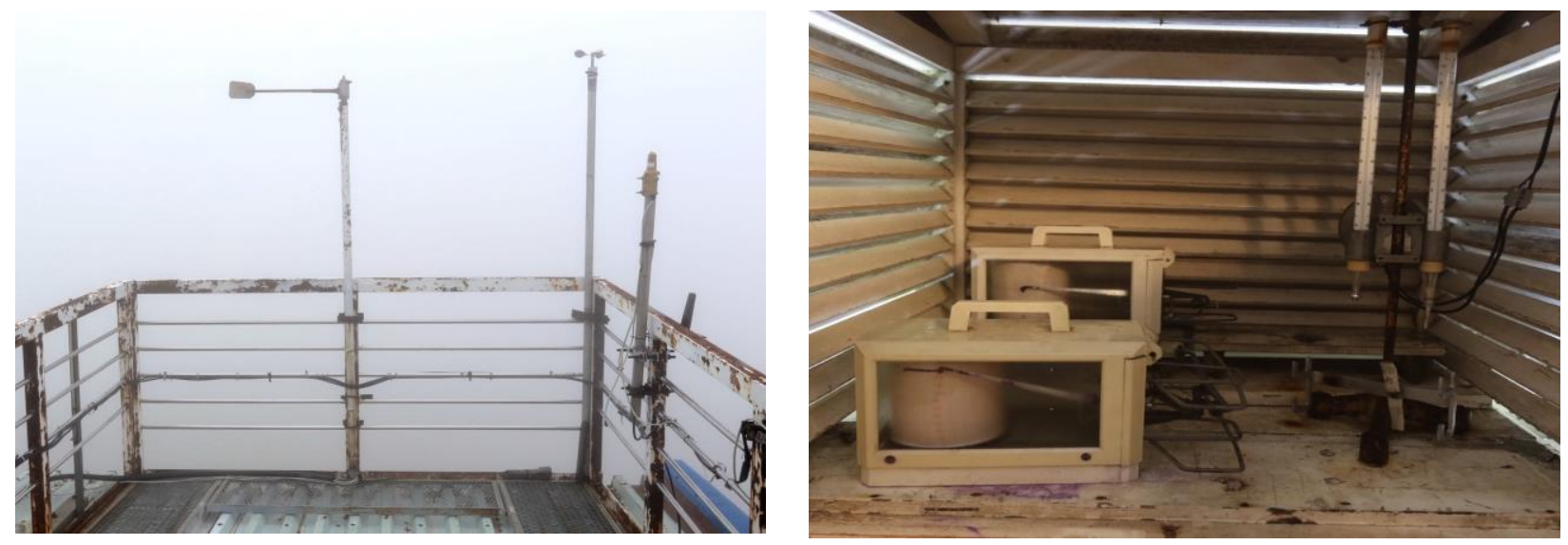

Fig. 2. Meteorological station Bjelasnica [3]

\section{Analysis of results}

This paper analyzes data obtained from the Federal Hydrometeorological Institute of Bosnia and Herzegovina related to the wind velocity in the area of Bjelasnica. Data obtained from the Federal Hydrometeorological Institute are the annual average wind velocity, average monthly wind velocity and maximum monthly wind velocity for the period from 2000 to 2010 [3]. The method used during the research is a linear regression method. The term linear regression refers to the method of modeling the dependence of the dependent stochastic variable on a set of independent variables in such a way that these dependences are linear. The simplest regression models use an independent meteorological variable. Basically, it is possible to construct regression models that use several meteorological variables. All regression coefficients of the forecasting model, depending on the type of regression method, are determined on the basis of statistical analysis of historical data on air movement [5], [6]. The wind velocity at which the wind turbine is driven are about $3 \mathrm{~m} / \mathrm{s}$, with electricity production being rather small. The optimum wind velocity is about $12 \mathrm{~m} / \mathrm{s}$ (max. electricity production), and with the further increase in wind velocity, the amount of electricity does not increase even at velocities of 25 to $30 \mathrm{~m} / \mathrm{s}$, the wind turbine is switched off due to the high mechanical load [8]. Figure 3 shows the results of the maximum and average wind velocity for the month of January in the period from 2000-2010 in the area of Bjelasnica.

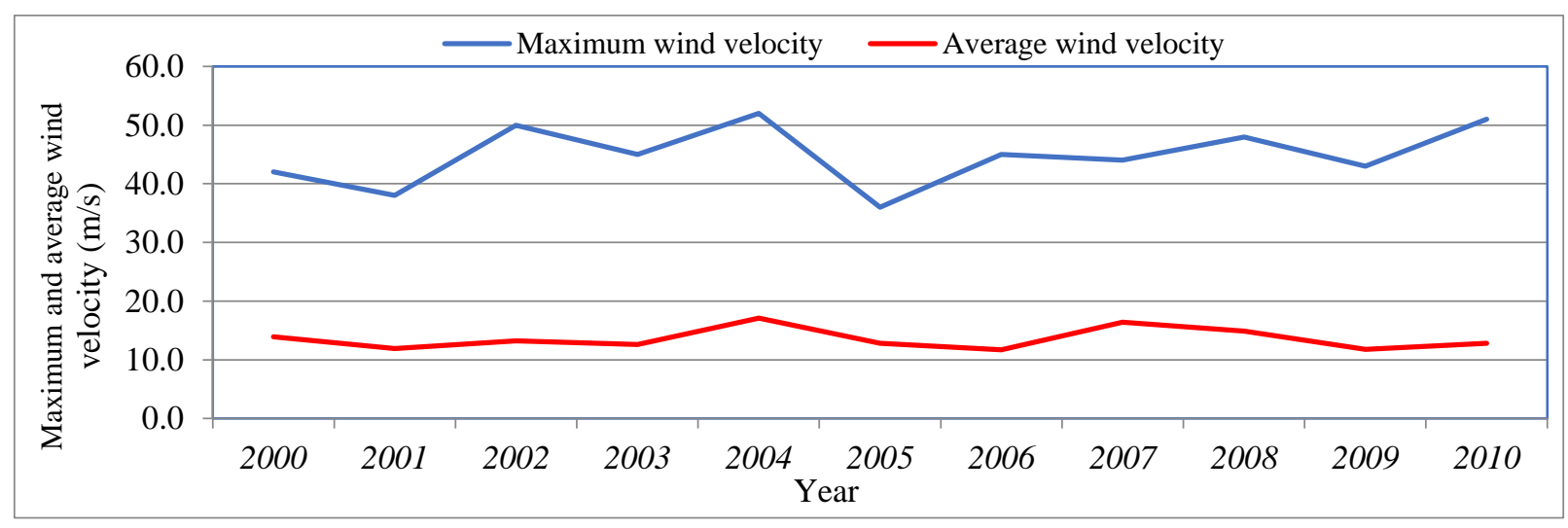

Fig. 3. Maximum and average wind velocity for the month of January in the period from 2000-2010 in the area of Bjelasnica [3] 
The lowest average wind velocity was $11,7 \mathrm{~m} / \mathrm{s}$ in January 2006 , while the highest average wind velocity was 17,1 $\mathrm{m} / \mathrm{s}$ in January 2004. The lowest wind velocity was $36 \mathrm{~m} / \mathrm{s}$ in January 2005, while the highest maximum wind velocity was $52 \mathrm{~m} / \mathrm{s}$ in January 2004. From Figure 3, it can be concluded that the maximum wind velocity was in the range of 36 to $52 \mathrm{~m} / \mathrm{s}$ for the period from 2000 to 2010, which means that the maximum values of the wind velocity are of high value and on these values comes wind turbines shutdown. While the average wind velocity ranges from 11,7 to $17,1 \mathrm{~m} / \mathrm{s}$, which is a sufficient condition for the operation of wind turbines and the production of the maximum amount of electricity. Figure 4 shows the results of the maximum and average wind velocity for the month of February in the period from 2000 2010 in the area of Bjelasnica.

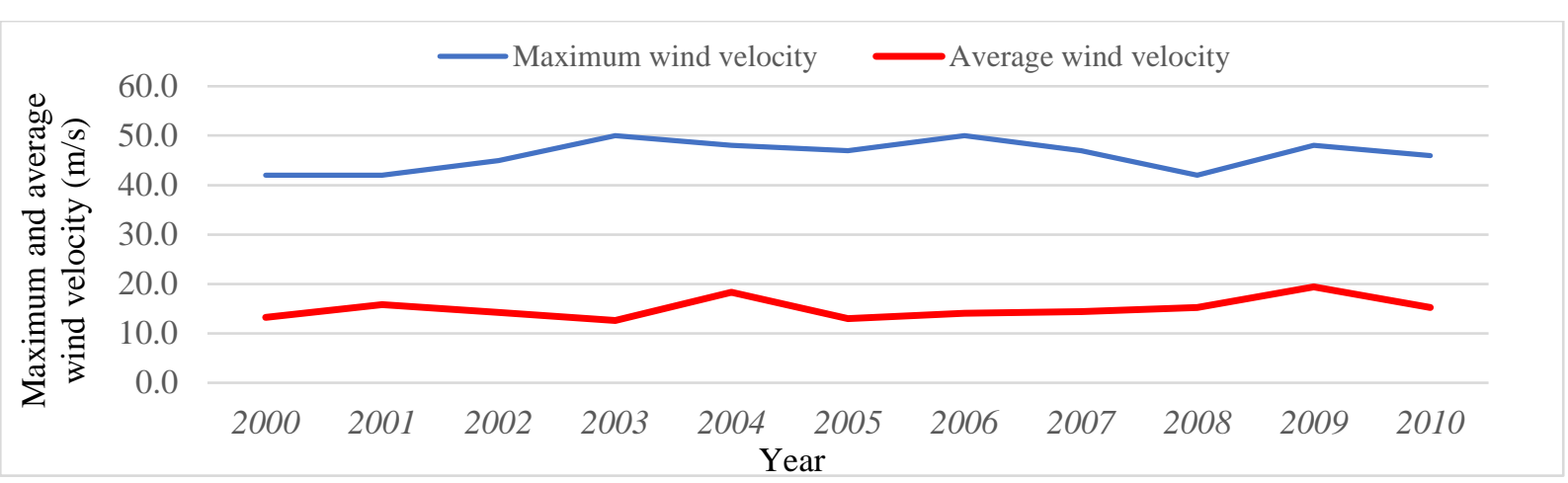

Fig. 4. Maximum and average wind velocity for the month of February in the period from 2000-2010 in the area of Bjelasnica [3]

The lowest average wind velocity was $12,6 \mathrm{~m} / \mathrm{s}$ in February 2003, while the highest average wind velocity was 19,4 $\mathrm{m} / \mathrm{s}$ in February 2009. The lowest maximum wind velocity was $42 \mathrm{~m} / \mathrm{s}$ in February 2000, 2001 and 2008, while the highest maximum wind velocity was $50 \mathrm{~m} / \mathrm{s}$ in February 2003 and 2006. From Figure 4, it can be concluded that the maximum wind velocity was range from 42 to $50 \mathrm{~m} / \mathrm{s}$ for the period from 2000 to 2010 , which means that the maximum values of the wind velocity are of high value and on these values comes wind turbine shutdown. However, the average wind velocity is high, so that the continuous operation of the wind turbine can be achieved. Figure 5 shows the results of the maximum and average wind velocity for the month of March in the period from 2000-2010 in the area of Bjelasnica.

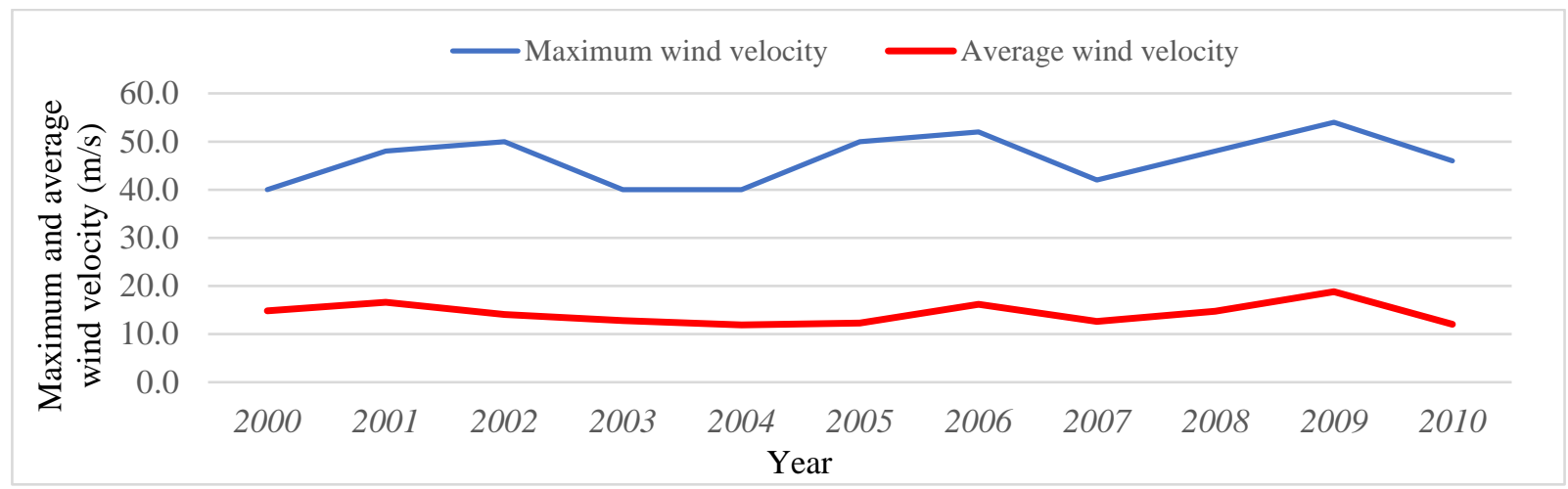

Fig. 5. Maximum and average wind velocity for the month of March in the period from 2000-2010. in the area of Bjelasnica [3]

The lowest average wind velocity was $11,9 \mathrm{~m} / \mathrm{s}$ in March 2004, while the highest average wind velocity was $18,8 \mathrm{~m} / \mathrm{s}$ in March 2009. The lowest maximum wind velocity was $40 \mathrm{~m} / \mathrm{s}$ in March 2000, 2003 and 2004, while the highest maximum wind velocity was $54 \mathrm{~m} / \mathrm{s}$ in March 2009. Based on the analysis of the results, it was concluded that there is enough wind velocity for continuous operation, but according to the analysis of the average wind velocity there are high values ranging from 11,9 to 18,8 m/s, which are sufficient for the operation of the wind turbine. Figure 6 shows the results of maximum and average wind velocity for the month of April in the period from 2000-2010 in the area of Bjelasnica. 


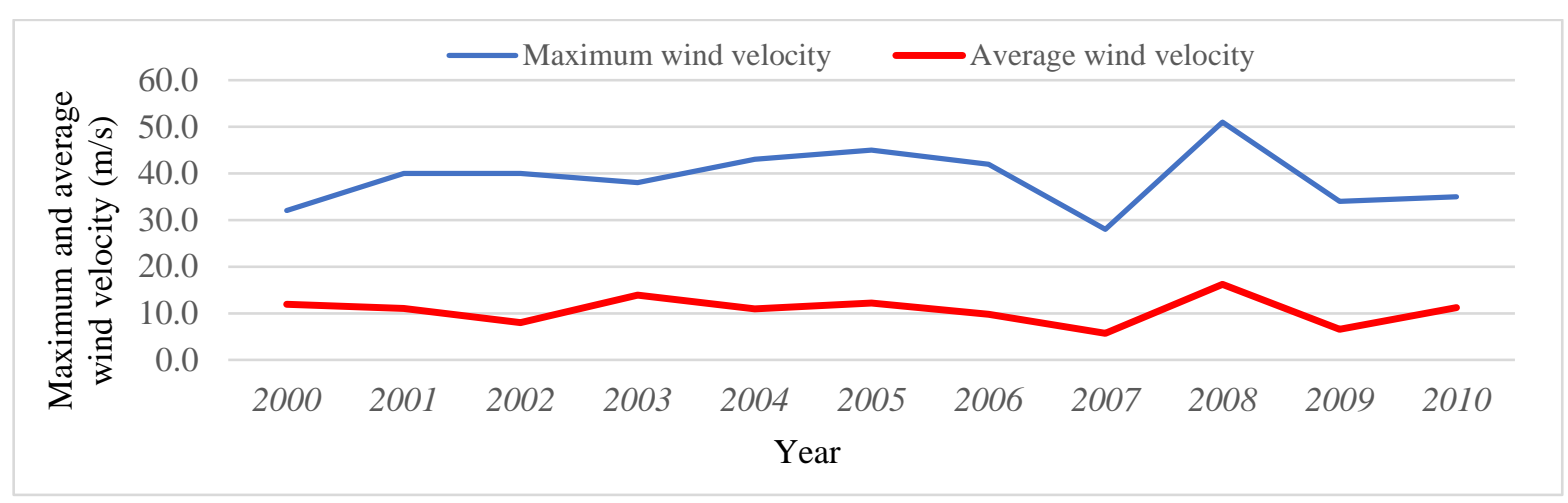

Fig. 6. Maximum and average wind velocity for the month of April in the period 2000-2010. in the area of Bjelasnica [3]

The lowest average wind velocity was $5,7 \mathrm{~m} / \mathrm{s}$ in April 2007, while the highest average wind velocity was $16,2 \mathrm{~m} / \mathrm{s}$ in April 2008. The lowest maximum wind velocity was $28 \mathrm{~m} / \mathrm{s}$ in April 2007, while the highest maximum wind velocity was $51 \mathrm{~m} / \mathrm{s}$ in April 2008. Based on the analysis of the results, it was concluded that there is enough wind velocity for continuous operation, but according to the analysis of the maximum wind velocity there are high values ranging from 28 to $51 \mathrm{~m} / \mathrm{s}$, which means that the maximum values of the wind velocity are of high value and on these values comes wind turbine shutdown. Figure 7 shows the results of the maximum and average wind velocity for the month of May in the period from 2000-2010 in the area of Bjelasnica.

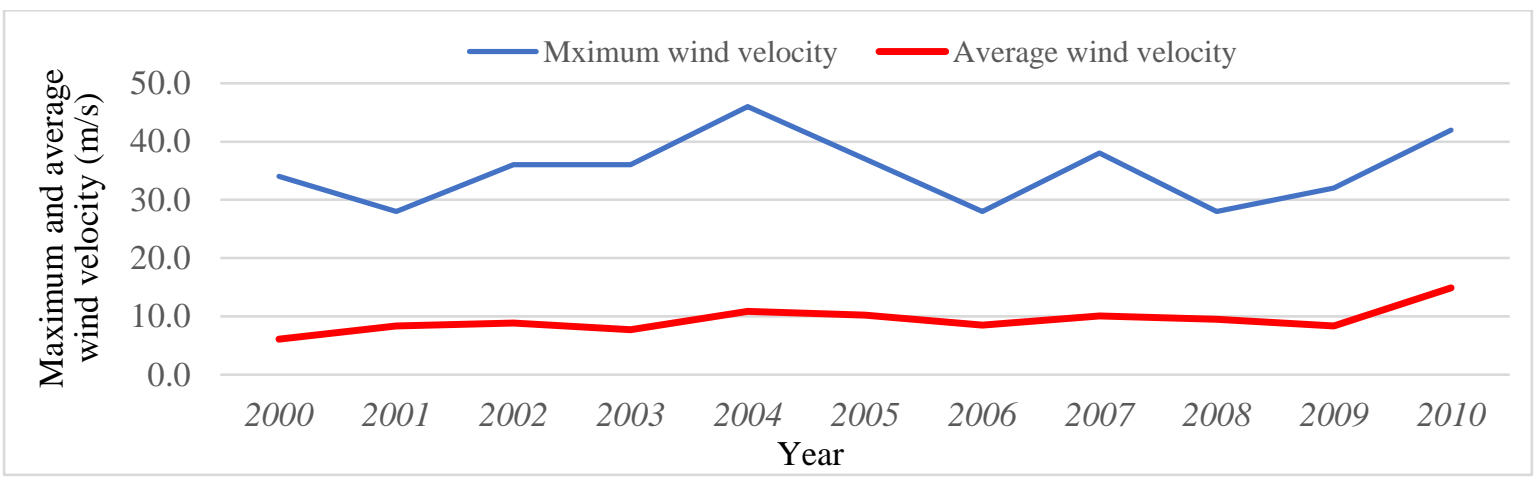

Fig. 7. Maximum and average wind velocity for the month of May in the period from 2000-2010 in the area of Bjelasnica [3]

The lowest average wind velocity was $6,1 \mathrm{~m} / \mathrm{s}$ in May 2000, while the highest average wind velocity was $14,9 \mathrm{~m} / \mathrm{s}$ in May 2010, from which it can be concluded that there is enough wind velocity for continuous operation. The lowest maximum wind velocity was $28 \mathrm{~m} / \mathrm{s}$ in May 2001, 2006 and 2008 while the highest maximum wind velocity was 46 m/s in May 2004, which means that the maximum values of the wind velocity are of high value and on these values comes wind turbine shutdown. Figure 8 shows the results of the maximum and average wind velocity for the month of June in the period from 2000-2010 in the area of Bjelasnica.

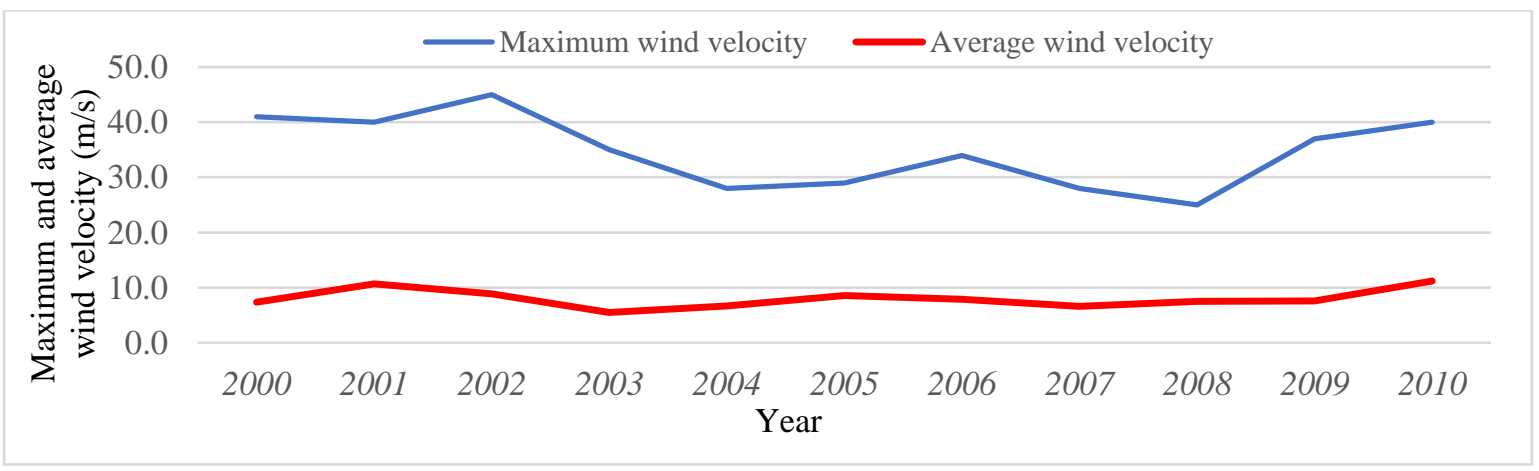

Fig. 8. Maximum and average wind velocity for the month of June in the period from 2000-2010 in the area of Bjelasnica [3] 
The lowest maximum wind velocity was $25 \mathrm{~m} / \mathrm{s}$ in June 2008, while the highest maximum wind velocity was $45 \mathrm{~m} / \mathrm{s}$ in June 2002, which means that the maximum values of the wind velocity are of high value and on these values comes wind turbine shutdown. The lowest average wind velocity was $5,5 \mathrm{~m} / \mathrm{s}$ in June 2003 , while the highest average wind velocity was $11,2 \mathrm{~m} / \mathrm{s}$ in June 2010 , from which it can be concluded that there is enough wind velocity for continuous operation. Figure 9 shows the results of the maximum and average wind velocity for the month of July in the period from 2000-2010 in the area of Bjelasnica.

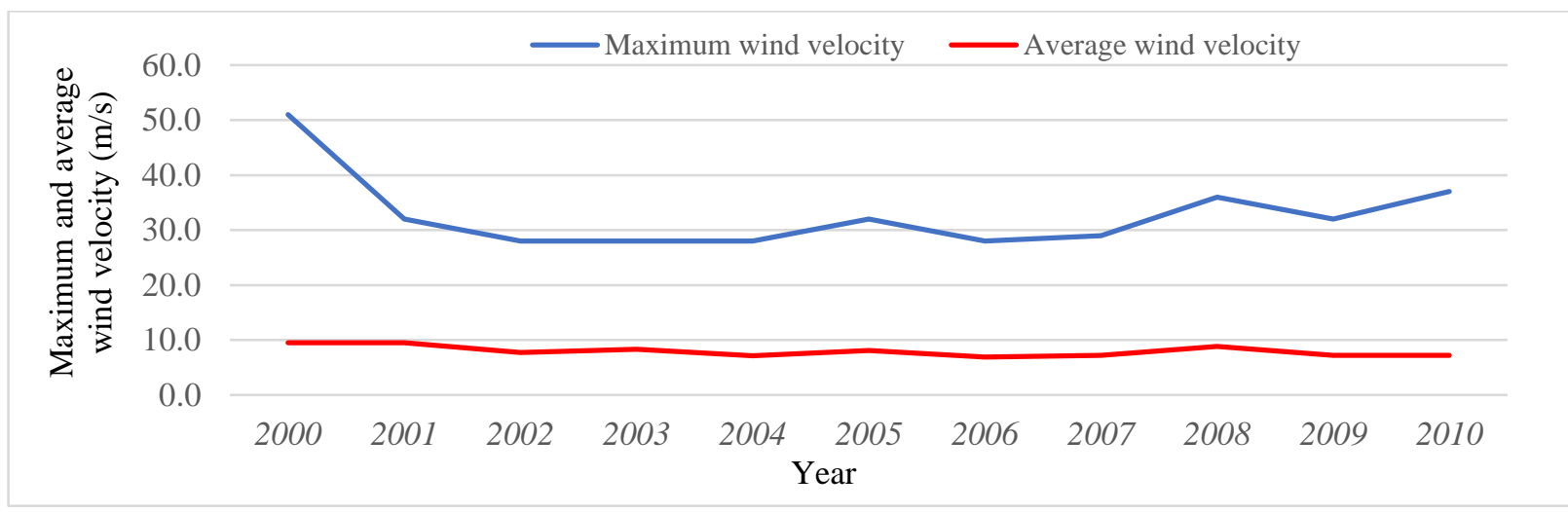

Fig. 9. Maximum and average wind velocity for the month of July in the period from 2000-2010 in the area of Bjelasnica [3]

The lowest maximum wind velocity was $28 \mathrm{~m} / \mathrm{s}$ in July 2002, 20032004 and 2006, while the highest maximum wind velocity was $51 \mathrm{~m} / \mathrm{s}$ in July 2000. When analyzing these obtained results, it can be concluded that the value of the maximum wind velocity ranges from 28 to $51 \mathrm{~m} / \mathrm{s}$, which means that the maximum values of the wind velocity are of high value and on these values comes wind turbine shutdown. The lowest average wind velocity was 7,1 m/s in July 2004 , while the highest average wind velocity for July was $9,5 \mathrm{~m} / \mathrm{s}$ in July 2000 and 2001, from which it can be concluded that there is enough wind velocity for continuous operation. Figure 10 shows the results of the maximum and average wind velocity for the month of August in the period from 2000-2010 in the area of Bjelasnica.

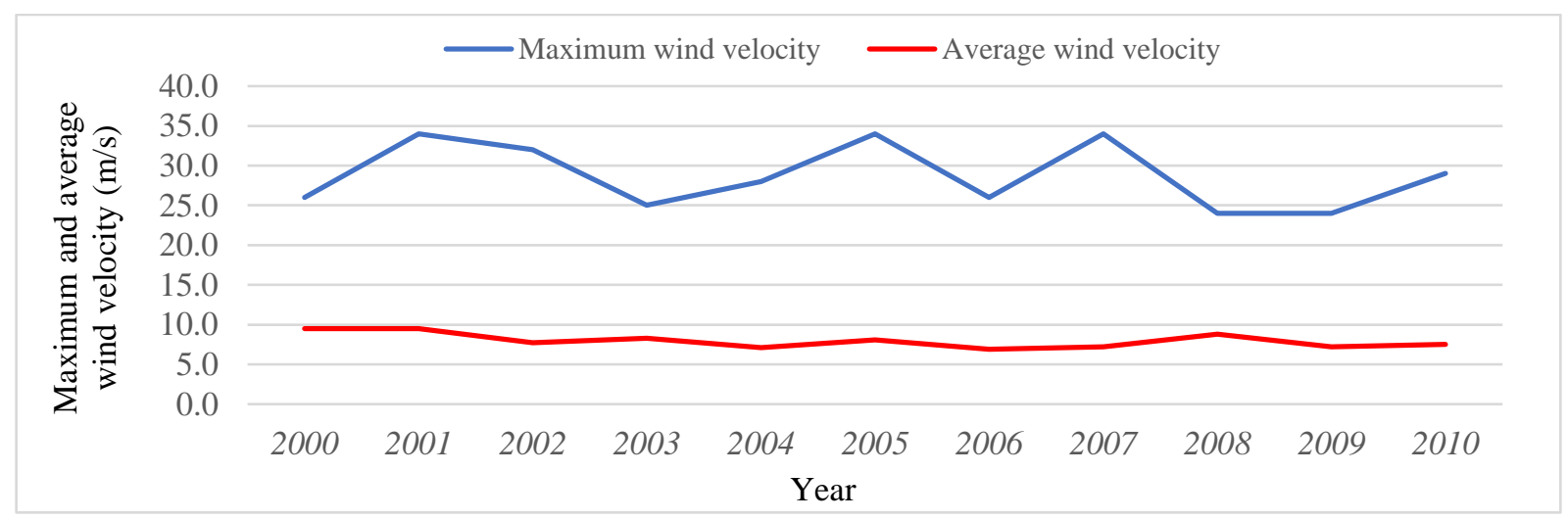

Fig. 10. Maximum and average wind velocity for the month of August in the period from 2000-2010 in the area of Bjelasnica [3]

The lowest maximum wind velocity was $24 \mathrm{~m} / \mathrm{s}$ in August 2008 and 2009, while the highest maximum wind velocity was $34 \mathrm{~m} / \mathrm{s}$ in August 2001 and 2005, which means that the maximum values of the wind velocity are of high value and on these values comes wind turbine shutdown. The lowest average wind velocity was $6,9 \mathrm{~m} / \mathrm{s}$ in August 2006, while the highest average wind velocity was 9,5 m/s in August 2000 and 2001, from which can be concluded that there is enough wind velocity for continuous operation. Figure 11 shows the results of the maximum and average wind velocity for the month of September in the period from 2000-2010 in the area of Bjelasnica. 


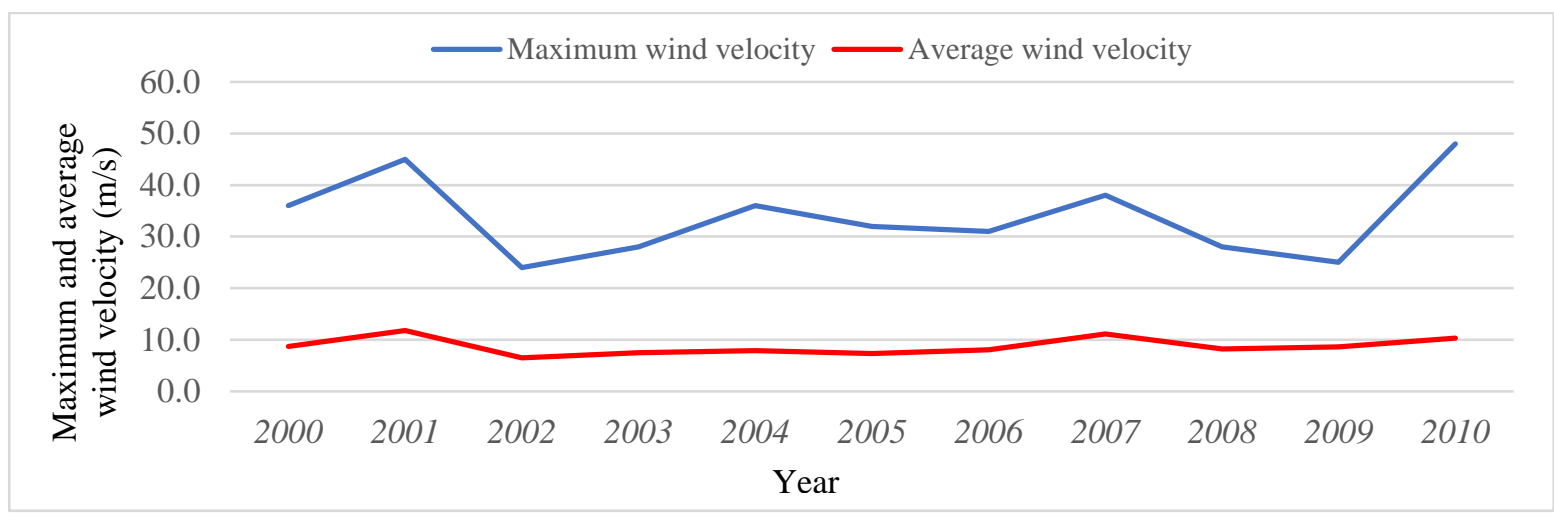

Fig. 11. Maximum and average wind velocity for the month of September in the period from 2000-2010 in the area of Bjelasnica [3]

The lowest maximum wind velocity was $24 \mathrm{~m} / \mathrm{s}$ in September 2002, while the highest maximum wind velocity was $48 \mathrm{~m} / \mathrm{s}$ in September 2010. The lowest average wind velocity was 6,5 m/s in September 2002, while the highest average wind velocity was $11,8 \mathrm{~m} / \mathrm{s}$ in September 2001. Figure 12 shows the results of the maximum and medium wind velocity for the month of October in the period from 2000-2010 in the area of Bjelasnica.

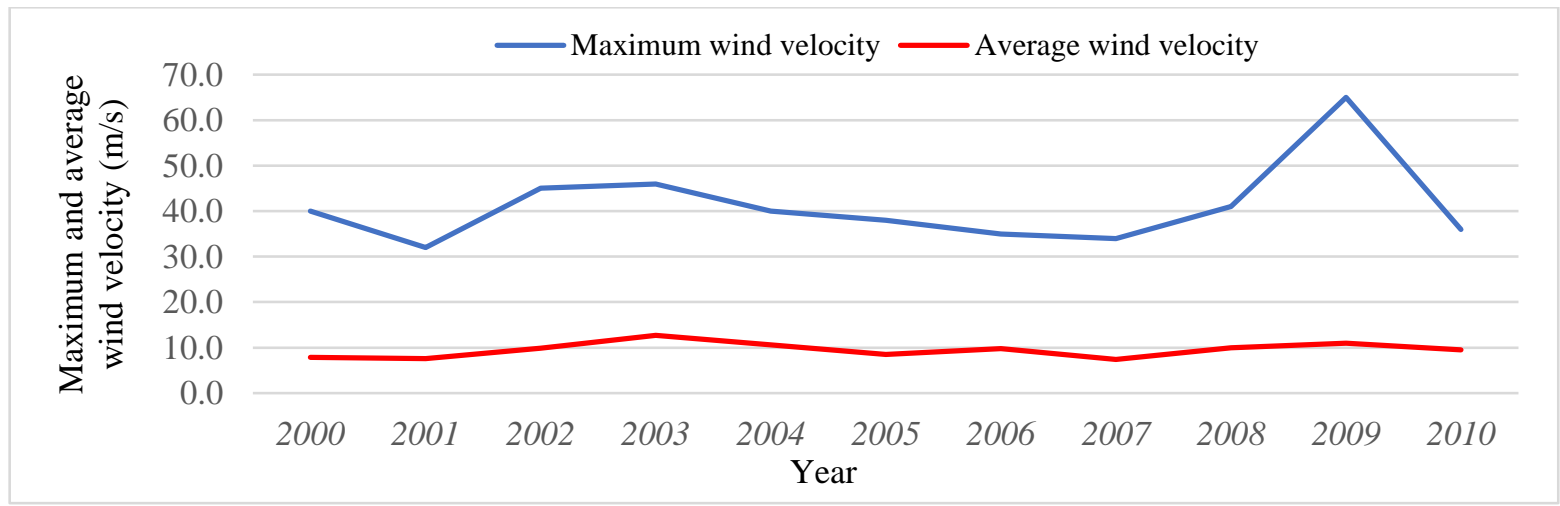

Fig. 12. Maximum and average wind velocity for the month of October in the period from 2000-2010 in the area of Bjelasnica [3]

The lowest average wind was $7,4 \mathrm{~m} / \mathrm{s}$ in October 2007 , while the highest average wind velocity was $12,7 \mathrm{~m} / \mathrm{s}$ in October 2003. The lowest maximum wind velocity was $32 \mathrm{~m} / \mathrm{s}$ in October 2001, while the highest maximum wind velocity was $65 \mathrm{~m} / \mathrm{s}$ in October 2009. Based on the analysis of the results, it was concluded that there is enough wind velocity for continuous operation, but according to the analysis of the maximum wind velocity there are values ranging from 32 to 65 $\mathrm{m} / \mathrm{s}$, which means that the maximum values of the wind velocity are of high value and on these values comes wind turbine shutdown. Figure 13 shows the results of the maximum and average wind velocity for the month of November in the period from 2000-2010 in the area of Bjelasnica.

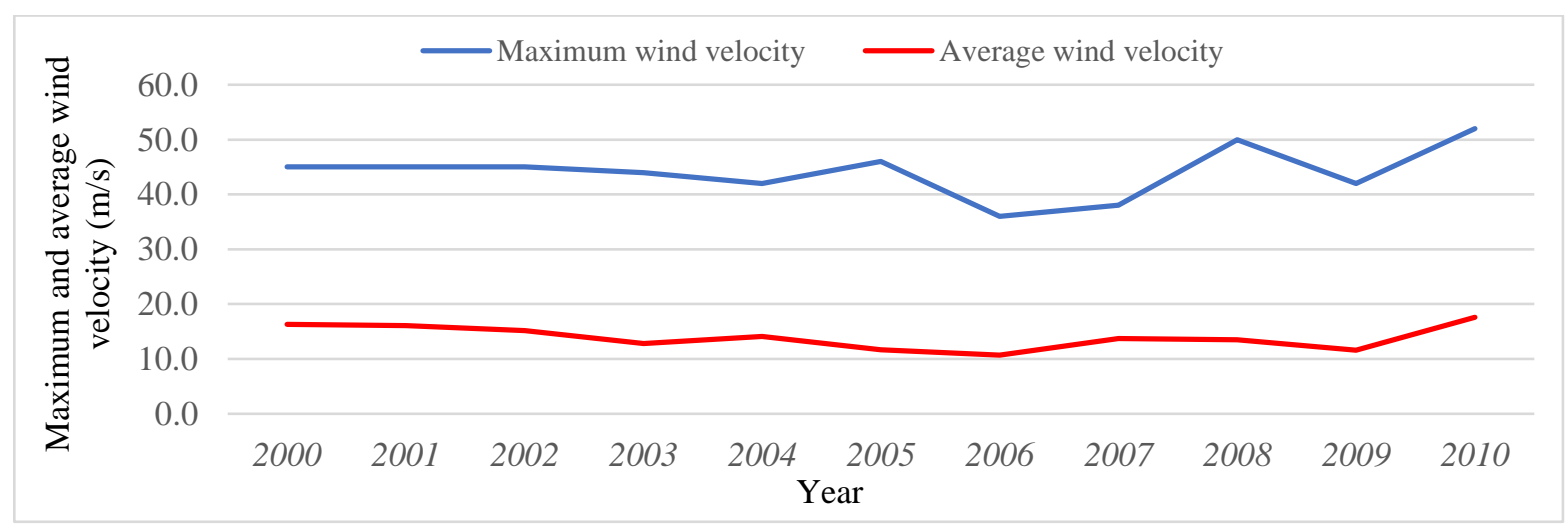

Fig. 13. Maximum and average wind velocity for the month of November in the period from 2000-2010 in the area of Bjelasnica [3] 
The lowest maximum wind velocity was $36 \mathrm{~m} / \mathrm{s}$ in November 2006, while the highest maximum wind velocity was $52 \mathrm{~m} / \mathrm{s}$ in November 2010. The lowest average wind velocity was 10,7 m/s in November 2006, while the highest average wind velocity was $17,6 \mathrm{~m} / \mathrm{s}$ in November 2010 . Based on the analysis of the results, it has been concluded that there is enough wind velocity for continuous operation, but according to the analysis of the maximum wind velocity there are high values ranging from 36 to $52 \mathrm{~m} / \mathrm{s}$, which means that the maximum values of the wind velocity are of high value and on these values comes wind turbine shutdown. Figure 14 shows the results of the maximum and average wind velocity for the month of December in the period from 2000-2010 in the area of Bjelasnica.

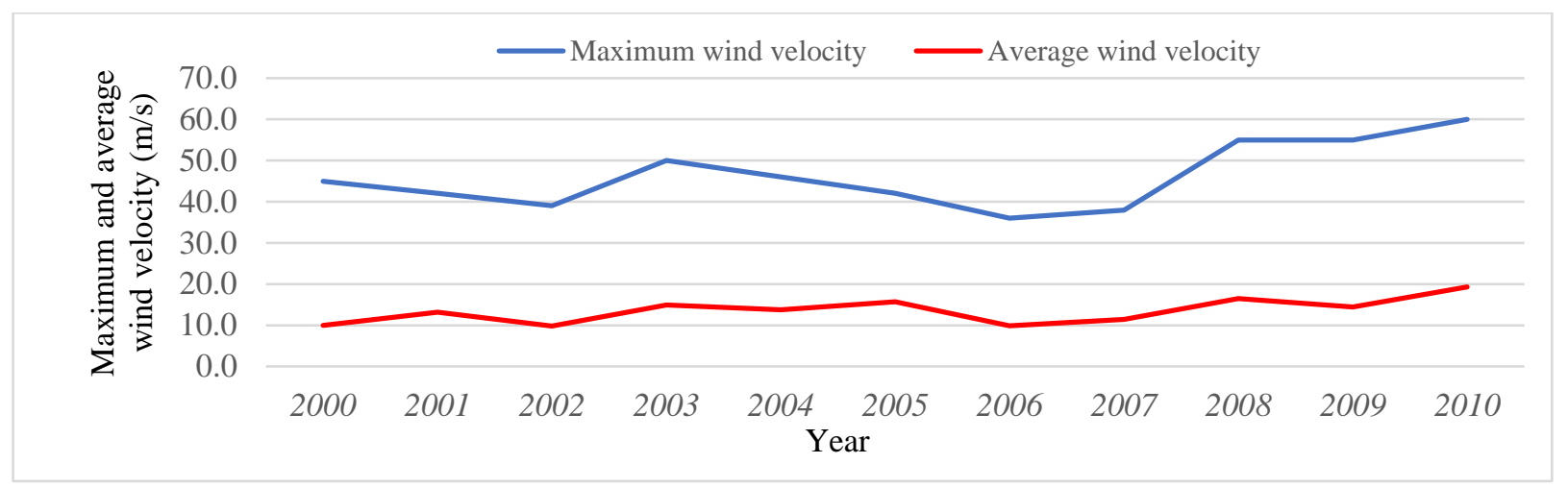

Fig. 14. Maximum and average wind velocity for the month of December in the period from 2000-2010 in the area of Bjelasnica [3]

The lowest maximum wind velocity was $36 \mathrm{~m} / \mathrm{s}$ in December 2006, while the highest maximum wind velocity was $60 \mathrm{~m} / \mathrm{s}$ in December 2010. The lowest average wind velocity was 9,8 m/s in December 2002, while the highest average wind velocity was $19,3 \mathrm{~m} / \mathrm{s}$ in December 2010. Based on the analysis of the results, it was concluded that there is enough wind velocity for continuous operation, but according to the analysis of the maximum wind velocity there are high values ranging from 36 to $60 \mathrm{~m} / \mathrm{s}$, which means that the maximum values of the wind velocity are of high value and on these values comes wind turbine shutdown.

\section{Wind rose}

Wind rose for meteorological station Bjelasnica from 2000-2010 is shown in Figure 15 [3]. The wind rose is a graphic representation of the average strength and wind velocity from certain directions. It is a polar diagram where the sides of the world are represented, which indicate the directions from which the wind blows. Figure 15 shows that the prevailing wind blowing directions are northwest, south and north winds and is conditioned by the basin morphology of the terrain.

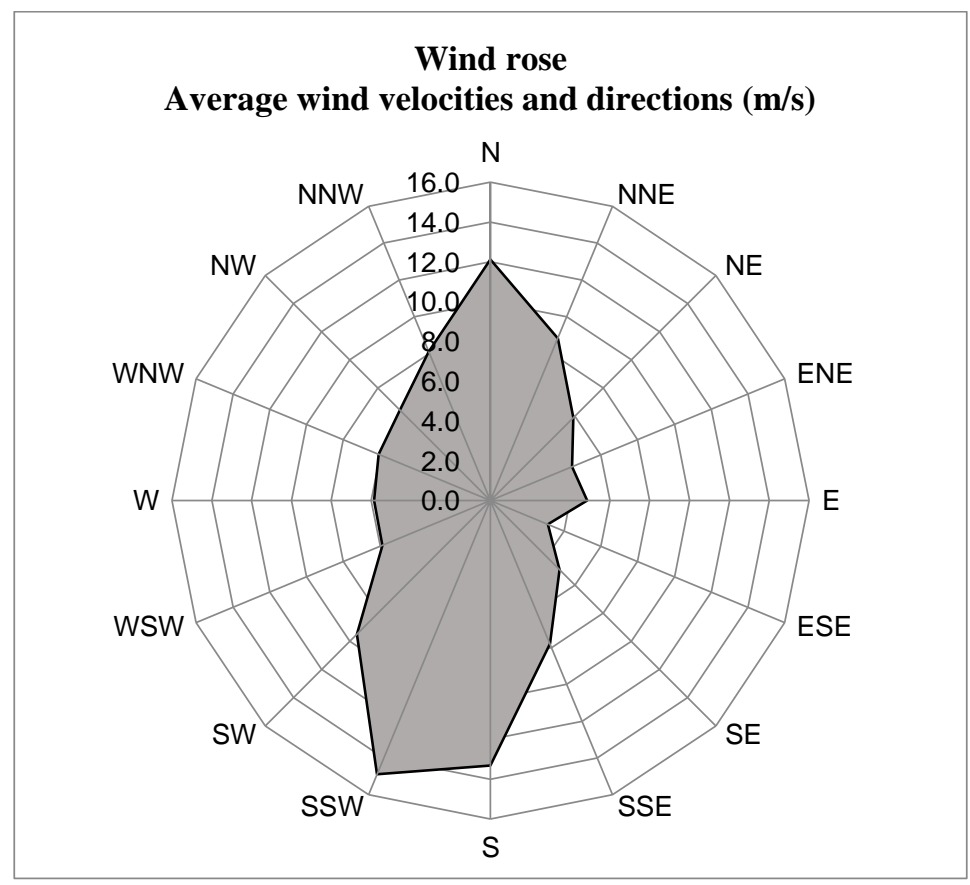

Fig. 15. Wind rose for meteorological station from 2000-2010 in the area of Bjelasnica [3] 


\section{Conclusion}

This paper analysis data obtained from the Federal Hydrometeorological Institute of Bosnia and Herzegovina related to the wind velocity in the area of Bjelasnica. Data obtained from the Federal Hydrometeorological Institute are average monthly wind velocity and maximum monthly wind velocity for the period from 2000 to 2010 . The method used during the research is a linear regression method. The analysis used tens of thousands of data related to wind velocity in the area of Bjelasnica for the period mentioned.

From this analysis of the maximum wind velocity for the period from 2000 to 2010 , it can be concluded that in the area of Bjelasnica, for the months November and December from 36 to $52 \mathrm{~m} / \mathrm{s}$. The maximum wind velocity was recorded in the month of October and it was $65 \mathrm{~m} / \mathrm{s}$. From other months, the maximum wind velocity ranges from 24 to $45 \mathrm{~m} / \mathrm{s}$.

From this analysis of the average wind velocity, it can be determined that the wind turbine does have continuous operation, since the values range from 5,5 to $19,4 \mathrm{~m} / \mathrm{s}$, and for the continuous operation of the wind turbine the average wind velocity should be above $3 \mathrm{~m} / \mathrm{s}$. In the continuation of this study, it is necessary to analysis the number of days with strong wind $(10,8-17,1 \mathrm{~m} / \mathrm{s}$ ) and the number of days with storm winds (above 17,2 m/s) for the period 2000-2010. In order to determine how many hours the wind turbine could work in a single day.

\section{Acknowledgments} Canton.

This paper is realized in framework of project supported by the Ministry of Education, Science and Youth of Sarajevo

\section{References}

[1] http://www.ekoakcija.org/(2008). Energetski institut Hrvoje Požar Croatia, Soluziona - Spain, Ekonomski institut Banjaluka -BH, Rudarski institut Tuzla -BH, Studija energetskog sektora u BiH, Modul 12 - Upravljanje potrošnjom, štednja energije i obnovljivi izvori energije, Accessed on: 2019-10-13

[2] Zlomušica, E.; Čampara, M. \& Dedić, R. (2015). Vjetroelektrane - osnove konstrukcije i rada, Agromediteranski fakultet Univerziteta „Džemal Bijedić“, ISBN: 978-9958-604-90-4, Mostar, Bosnia and Herzegovina

[3] http://fhmzbih.gov.ba/latinica/ (2019). Federalni hidrometeorološki zavod Bosne i Hercegovine, Accessed on: 2019-03-09

[4] Hadziahmetovic, H.; Dzaferovic E.; Ahmovic, I. \& Blazevic, R. (2018). Analysis of Wind Velocity Data in the Area of the City of Sarajevo in Period from 2001-2010, Proceedings of the 29th DAAAM International Symposium, Zadar, Croatia, ISSN 1726-9679, ISBN 978-3-902734-20-4, B. Katalinic (Ed.), pp.0250-0259, Published by DAAAM International, Vienna, Austria, DOI: 10.2507/29th.daaam.proceedings.036

[5] Gasch, R. \& Twele, J. (2012). Wind Power Plants- Fundamentals, Design, Construction and Operation Second Edition, Springer-Verlag Berlin Heidelberg, ISBN: 978-3642229374, Berlin, Germany

[6] Spera, D. A. (2009). Wind Turbine Technology: Fundamental Concepts in Wind Turbine Engineering, American Society of Mechanical Engineers, ISBN: 9780791802601, New York, USA

[7] www.mvteo.gov.ba, (2016). Ministarstvo vanjske trgovine i ekonomskih odnosa Bosne i Hercegovine, Akcioni plan za korištenje obnovljive energije u Bosni i Hercegovini, Accessed on: 2019-10-10

[8] Manwell, J.F.; McGowan, J.G. \& Rogers, A.L.(2009). Wind Energy Explained: Theory, Design and Application Second Edition, John Wiley \& Sons, Ltd, ISBN:9780470015001, Chichester, UK. 